\title{
Beyond coping with chronic NCDs: reflections on paradigms in one Brazilian Health Promotion Programme
}

\author{
Para além do enfrentamento das DCNTs: reflexões paradigmáticas sobre o Programa Ministerial \\ Academia da Saúde, no Brasil \\ Más allá de enfrentar las ENT: reflexiones paradigmáticas sobre el Programa Ministerial \\ Academia da Saúde, en Brasil
}

Received: 01/02/2021 | Reviewed: 01/03/2021 | Accept: 01/08/2021 | Published: 01/09/2021

Fernanda Ramos Parreira ORCID: https://orcid.org/0000-0001-8168-9185 Secretaria de Estado da Saúde de Goiás, Brazil E-mail: fernandarparreira@gmail.com

Marta Rovery de Souza

ORCID: https://orcid.org/0000-0001-6910-843X Universidade Federal de Goiás, Brazil E-mail: martary@gmail.com

\begin{abstract}
This study provides reflections on the hybridisation of paradigms resulting from the creation of the Academy of Health Programme created by the Brazilian National Ministry of Health. This was a descriptive study, analysing the National Health Promotion Policy (first published in 2006 and revised in 2014), the National Strategic Action Plan to Battle Chronic Non-Communicable Diseases (NCDs) and the Academy of Health Programme (established by Ordinance no. $719 / \mathrm{GM} / \mathrm{MS}$ in 2011). The scientific disputes seen during the development of the programme have had an impact on the practices it advises and on its implementation. We reflect that the Academy of Health Programme can and should create a space where, beyond the chronic NCDs, the model of dominator and dominated can be subverted and the transformation idealised by collective health through the health promotion movement can be made concrete.
\end{abstract}

Keywords: Health promotion; National health programmes; Chronic non-communicable diseases; Medical sociology.

\section{Resumo}

Este estudo presta-se a refletir sobre as hibridizações paradigmáticas presentes na constituição do Programa Academia da Saúde, criado pelo Ministério da Saúde, no Brasil. A pesquisa consiste em um estudo descritivo, analisando a Política Nacional de Promoção da Saúde (2006 e 2014), Plano de Ações Estratégicas para Enfrentamento das Doenças Crônicas Não-Transmissíveis (DCNTs) e Portaria n 719/GM/MS, de 7 de abril de 2011, de instituição do programa ministerial. As disputas científicas presentes na elaboração do programa refletem nas práticas e na implementação do mesmo. O artigo trata de apontar que para além das DCNTS, o programa tem potencial de construção de sujeitos autônomos, empoderados e protagonistas de suas vidas e corpos.

Palavras-chave: Promoção da saúde; Programas nacionais de saúde; Doenças crônicas não-transmissíveis; Sociologia médica.

\section{Resumen}

Este estudio ofrece reflexiones sobre la hibridación de paradigmas resultantes de la creación del Programa Academia de Salud creado por el Ministerio de Salud Nacional de Brasil. Este fue un estudio descriptivo, analizando la Politica Nacional de Promoción de la Salud (publicada por primera vez en 2006 y revisada en 2014), el Plan de Acción Estratégico Nacional para Combatir las Enfermedades Crónicas No Transmisibles (ENT) y el Programa de la Academia de Salud (establecido por la Ordenanza no. 719 / GM / MS en 2011). Las disputas científicas observadas durante el desarrollo del programa han repercutido en las prácticas que asesora y en su implementación. Reflexionamos que el Programa Academia de Salud puede y debe crear un espacio donde más allá de las ENT crónicas, se pueda subvertir el modelo de dominador y dominado y concretar la transformación idealizada por la salud colectiva a través del movimiento de promociónn de la salud.

Palabras clave: Promoción de la salud; Programas nacionales de salud; Enfermedades crónicas no transmisibles; Sociología de la salud.

\section{Introduction}

In the health sciences, a new paradigm emerged because of the collapse of the health care system in the mid-1970s. The 
health care model in place at the time-based on liberal, individualistic, commercial, biology-oriented and hospital-centric principles - did not meet the social demands and needs that had arisen in the 20th century (Fontes, 1995). The changes in the epidemiological and demographic scenario pointed to the need for a health care model that was adaptable to those changes and the health problems that emerged from them.

The health promotion led to growth in the popularity of acting in a scenario focused on collectivity (Withelaw, 2001). Therefore, there was a need for a health model that intersects with socio-cultural aspects, under a broader definition of health. Such a model was initially discussed in North American countries, such as Canada, at the end of the 20th century, now having been implemented and disseminated to other western countries as a reference model that can be reproduced locally. This change in the definition of health and in the health model does not occur spontaneously and without a temporal context; on the contrary, "[the] structural properties of social systems exist only in so far as the forms of social conduct are reproduced chronically across time and space." (Giddens, 2009 p. 22).

This study provides reflections on the hybridisation of paradigms as a result of the creation of the Academy of Health Programme by the Brazilian National Ministry of Health. It is based on ministerial documents and publications — the Política Nacional de Promoção da Saúde (PNPS, National Health Promotion Policy; first published in 2006 and revised in 2014); the National Strategic Action Plan to Battle Chronic Non-Communicable Diseases (NCDs); and Ordinance no. 719/GM/MS, issued in 2011 (to establish the Academy of Health Programme) - and had the objective of analyzing, from an epistemological standpoint, the design of the ministerial programme in question.

To perform an interpretative analysis of the structure of the Academy of Health Programme, we have divided this article into two sections. In the first, we discuss two paradigms present in the context of health in Brazil: the biomedical model and the social production of health model. In the second section, we seek to identify, within the normative-legal documents that led to the creation of the Academy of Health Programme, the paradigmatic models that support it and that influence the practices and circumstances of the individuals who are active in the programme.

\section{Methodology}

The present study is the documentary type associated with case study, because analyze the documents published by the Ministry of Health related to the ministerial program Academia da Saúde; in focus, the Health Promotion Policy and the National Strategic Action Plan to Battle Chronic Noncommunicable Diseases. Develop a critical and comparative analysis of the concepts, theories and specific paradigms is present in each document investigated.

That paper approach the content analyze. It is noteworthy that for the development of content analyze, the criteria created by Badin (2011) were considered: pre-analysis; explore the material and treat the results. And adopted analytical categories are: conception, theoretical position, principles and values, objectives; and prioritized themes.

\section{From the Biomedical Model To the Social Production of Health Model: Paradigms in transition}

In the health care field, it is possible to envisage a clash between the medical sciences and the health sciences; between a biomedical/Flexnerian paradigm and a social paradigm of health/social determination; or between curative/preventive practice and health promotion (Fontes, 1995; Lopes, 1970; Scliar, 2005). This dichotomy corresponds to the struggle between two distinct poles that both seek to become accepted, as well as to have their concepts, practices and ideals legitimised.

The biological concept is actually a political concept (Agamben, 2017; Butler, 2015). In modern society, physical interventions, whether through medical or gymnastic practices, within the scope of altering the physical condition of the individual, are nothing more than political and social decisions.

The medicalisation process and the hospital-centric model, in conjunction with hygiene, physical education and curative 
practices, form a legitimate, hegemonic system. In this context, relationships of trust serve to legitimise the actions and positions constructed by expertise and by the established, legitimised health care system.

The concept of care is involved in a relationship of dominance and regulation; such relationships of use make self-care necessary (Agamben, 2017). For Agamben (2017, p. 54), "[although the use of the body] is the primary dimension in which subjectivity is constituted, the relationship of use remains in the shadows and gives rise to a* primacy of care over use." Within this relationship of control and regulation that permeates the use and care of the body, it is possible to highlight physical activities/physical practices as an effective mechanism for the implementation of new habits, customs and lifestyles.

In this scenario of the formation of a modern capitalist society, medicine, by incorporating elements inherent in that society, presents itself as a clinical science. This structuring of the medical field clearly marks a shift from the magico-religious paradigm to the biomedical model, the belief in miracles and supernatural forces being supplanted and the sickbed being transformed into a field of scientific research and discourse (Foucault, 1977).

The biomedical model presents itself as the first model of denial of disease, in which a world without patients is envisioned (Lefevre and Lefevre, 2004). In that model, the expert authority is the one with the competence and expertise to combat disease in a specific individual (i.e., a patient).

The physician-patient relationship is built on the conditions afforded by modernity, because the notions of disengagement and (re)engagement lead to a reshaping of social relationships, based on trust in abstract systems and expert knowledge (Giddens, 1991, 2009). It is thought that more people now live in circumstances in which disengaged institutions, linked to local practices and globalised social relationships, are active in their everyday lives. The physician, as health authority and keeper of the expert knowledge of this system, assumes the role of the generator of reliability and fidelity in the health field. Giddens (1991, p. 97) stated that "Individuals in pre-modern settings, in principle and in practice, could ignore the pronouncements of priests, sages and sorcerers and get on with the routines of daily activity. But this is not the case in the modern world, in respect of expert knowledge."

Expert knowledge institutes new values, beliefs and habits, which are reproduced by 'patients' in their daily life. Routinisation stems from interpersonal relationships between agents, generating trust in abstract systems and expert systems. This process of routinisation is carried out through social integration and system integration, given that integration implies reciprocity of practices, creating a relationship of autonomy or dependence between actors and collectivities (Giddens, 1991).

The 18th century model of health, designated the biomedical model, began, at the end of the 20th century, to undergo a process of exhaustion that allowed the genesis of a model that fits into sociological frameworks. At first, the new paradigm was called social medicine. Now, in the 21 st century, it is known as the social production of health model. This new paradigm builds on the reflexivity of social life, and "[. . .] social practices are constantly examined and reformed in the light of incoming information about those very practices, thus constitutively altering their character." (Giddens, 1991, p. 49). The change from the biomedical, Flexnerian or circular model to the social production of health model represents a shift in social practices in health and a shift from rationality to reflexivity. According to Ianni (2008, p. 41), "[ . . ] reflexivity is the supreme stage of enlightened, triumphant dominance over the earth, nature and humanity."

That perception is supported by Giddens (1991), who attributed it to the sense of lack of control and uncertainty in modernity, recognising as a false thesis the idea that increasing knowledge about life allows, in equal proportion, greater control over the destiny of society. In that regard, Giddens (1991) discussed the issue of the current state of society-modern or postmodern - and here it is thought that, as a result of the process of paradigmatic change, during which the traditional health model and the emerging health model coexist, the consequences of modernity are experienced.

Health has now come to be analysed beyond the biological, physiological and pathological, as its existence or absence is substantially influenced by political decisions and by the social conditions created. One example is the relationship between 
the level of education of a mother and the living conditions of her children. It is evident that a higher level of maternal education translates to better childhood living conditions and health status. That relationship is also intertwined with the opportune living conditions typically guaranteed to a mother with a higher level of education.

International organisations such as the World Health Organisation (WHO) and the United Nations, focusing on the 2030 agenda, have proposed actions and policies aimed at gender equity and improvements in the health and well-being of society, with a view toward having a positive impact on the lives of girls, eradicating or reducing the rates of early marriage/pregnancy and child labour, as well as increasing their access to and permanence in school, among other effects outlined in the United Nations Population Fund report 'State of World Population 2016'. Public health care systems then incorporate this new health paradigm into their policies and programmes.

Carvalho (2004), Lefevre and Lefevre (2004) and Ianni (2008) recognised the crisis and the exhaustion of the biomedical paradigm, or circular relationship model, resulting from the changing sociodemographic and epidemiological landscape, as well as the emergence of new challenges and new socio-political issues, the biomedical model having proved to be inefficient and full of oversights due to the complexity of living conditions.

New models, approaches and paradigms, such as the health promotion model, have come to the fore in advanced capitalist countries, including Canada, the United States and Western European countries; in Brazil, the collective health model is evident (Withelaw, 2001).In the Brazilian model, the health movement assumes the basic principles of and is linked to the perspective of the social determination of health.

Health promotion in the public health scenario is a recent trend worldwide and in Brazil. It is part of the premise of the positive concept of health, because it makes it comprehensible from a broad perspective and beyond the absence of illnesses, unlike preventive practice, which seeks to anticipate the disease process and take action to prevent it, as well as to ensure the treatment and control of diseases. Health promotion does not specifically target disease and illness processes, rather being focused on ensuring individual and collective quality of life and well-being (Czeresnia, 2003; Lefevre and Lefevre, 2004, 2007).

Lefevre and Lefevre (2004, p. 34) pointed out that "[ . . ] to understand health promotion as a paradigm shift, we must also be willing to enter into a discussion that distinguishes between health promotion and disease prevention, as prevention is still associated the old paradigm."

Health promotion is an area that presents many political, social and epistemological challenges. That reflects the different strands that are engendered for the field: the traditional strand-behaviourist and preventive health promotion; and the 'new health promotion' strand, which considers the social determination of health (Minowa, 2016).

Czeresnia (2003, p. 01) stated that "[the] public health discourse and the perspectives of redirecting health practices have, in the last two decades, come to be coordinated around the idea of health promotion." Initiated in advanced capitalist countries such as the United States, Canada and England, the concept of health promotion was disseminated to emerging economies such as Chile and Brazil.

The perspective of health promotion, as previously mentioned, emerges under a new configuration of public health, which is based on the new health paradigm - anchored in the social production of health-being considered the emerging paradigm. Therefore, new practices, new processes, new policies and new strategies have appeared, including health surveillance, health promotion, the encouragement of healthy activities (at the municipal and regional levels), collective health and community health (Carvalho, 2004; Heidmann et al., 2006; Santos and Westphal, 1999; Withelaw, 2001). Changes in health paradigms have been reflected in changes in reference models, health practices, health work processes, the organisation of health services and, especially, public policies. 


\section{The National Strategic Action Plan to Battle Chronic NCDs, the PNPS and the Academy of Health Programme: Between Control and Personal Autonomy}

Just as new scientific paradigms emerge when the current paradigm no longer meets the theoretical-social needs and demands, public policies are designed in response to new social and political demands, anchored in the interests, values and beliefs of certain societal groups (Sabatier, 1995, 2007).

Kingdon (2007, p. 105), in debating the choice of a public agenda, raised the following questions: "Why do some subjects rise on the agenda while others are overlooked?"; and "Why are some alternatives given more attention than others?". The author answered those questions by highlighting the roles of the participants and actors involved in such decisions.

In Brazil, the historical and political context of public health includes theoretical-conceptual, political and social transitions, which have been especially pronounced after the redemocratisation of the country in the late 1980s. The visibility of new actors and new institutional arrangements allowed the change from a treatment model to a care model (Paim, 2009; Mendes, 1996; Brasil, 2011b). As stated by Paim (2009, p. 41), "Although the right to health has been recognised internationally since the creation of the WHO in 1948, Brazil did not formally recognise health as a social right until 40 years later." Paradigm shifts in health have resulted in changes in reference models, health practices, health work processes, the organisation of health services and, especially, the public policies established.

Paim (2009) pointed out that the health care system is composed of agents (health professionals and health workers) and agencies (public and private institutions or entities).Other agents acting within this system include middle- and high-ranking bureaucrats, politicians (legislators), prosecutors, judges and representatives of civil society (health service users and health advisers).

It should be borne in mind that international organisations influence the shaping of public policies at the national and local levels. Notably, the agendas and themes prioritized by organisations such as the WHO and Pan American Health Organisation are incorporated into national and local agendas.

The Brazilian health care system was influenced by the Canadian matrix that was guided by the concept of health as a right of citizenship, organised in a decentralised way, being anchored in health promotion, disease prevention and intersectoral cooperation, as pointed out by Mendes (1996). The Brazilian health reform movement carried, together with its aspirations and goals of building a new democratic health system, the new concept of public health that intersects with the social sciences, especially sociology, even influencing the political process of the redemocratisation of Brazil.

The organisation of national health policies was systematised in Consolidation Ordinance no. 2, issued in 2017 (Figure 1). That ordinance linked the National Health Policy to general policies of health promotion, protection and recovery and is referenced in other health policies - policies for disease control and for combating health problems; health policies targeting specific segments of the population; and policies aimed at achieving health care equity. 
Figure 1. Organisation of national health policies in Brazil.

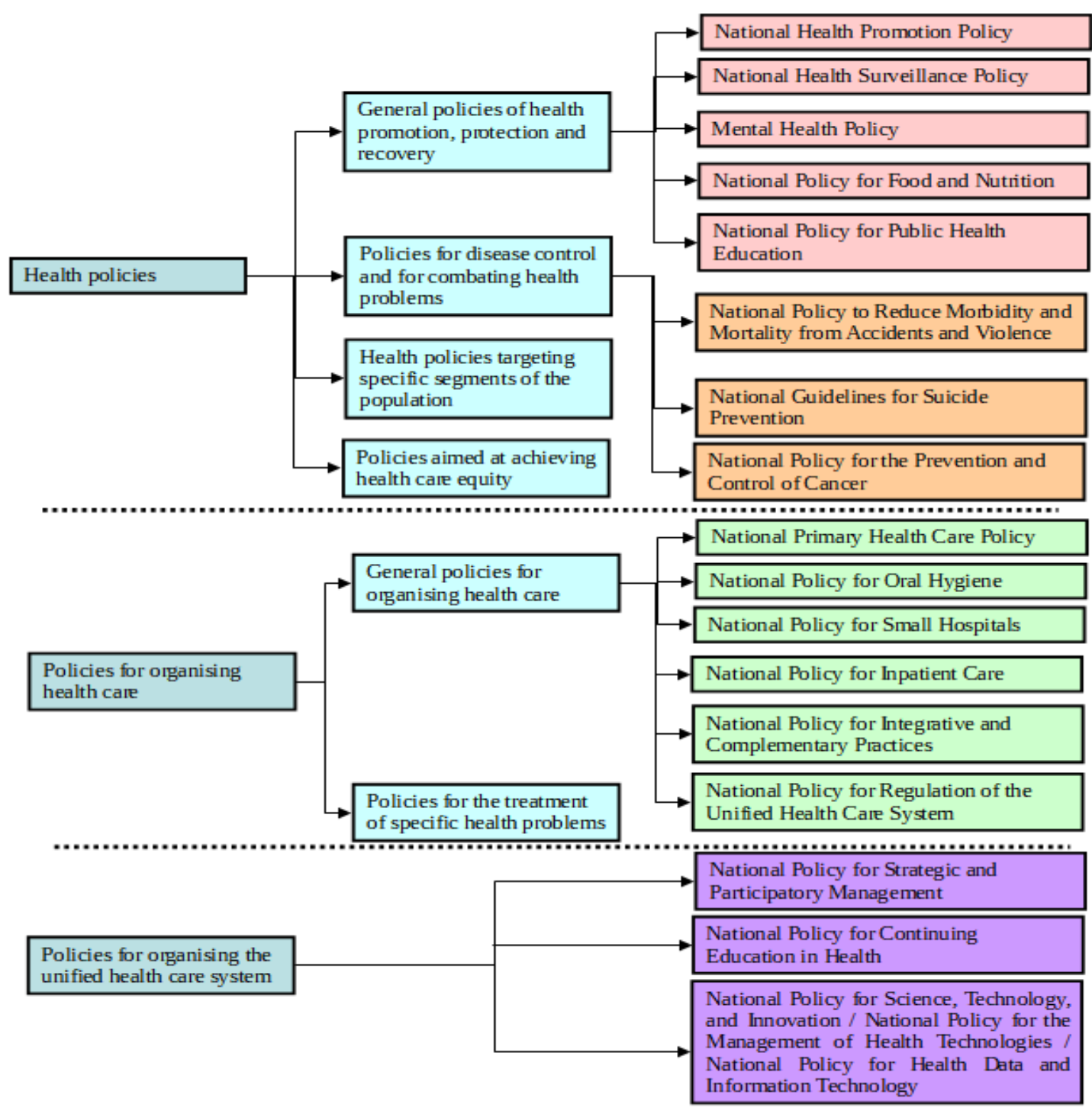

Source: Brasil (2017).

It is of note that public health policies in Brazil are interconnected by the principles and guidelines that constitute the Brazilian Sistema Único de Saúde (SUS, Unified Health Care System). Therefore, it is evident that several policies, in different axes and matrices, are linked to the PNPS.

The PNPS, especially in its revised version, has a broad perspective, as explained in Article 2 of Ordinance no. 2,446 in 2014: "[the] PNPS is based on an expanded concept of health and the theoretical framework of health promotion as a set of strategies and ways of producing health, both individually and collectively, characterised by coordination and cooperation within and between sectors, by forming the Health Care Network, seeking to coordinate its actions with those of other social protection networks, with broad participation and social control " (Brasil, 2014). That has made it a crucial strategy for the implementation of other policies (Figure 1). Thus, health promotion in Brazil, anchored especially in the Canadian model, provides an opportune way to change the behaviour of individuals and the lifestyles of the population in order to confront the main causes of chronic NCD-related morbidity and mortality, as presented in the first version of the PNPS, published in 2006.

The first model of health promotion was constructed close to the current, preventive model and, in a reductionist manner ended up being understood at the primary prevention level. The confusion and contradictions found in health promotion 
programmes and policies "[. . . stem from the strong emphasis on individual behaviour modification and the almost exclusive focus on controlling risk factors for certain diseases" (Buss, 2003, p. 34).

In Brazil, the legal framework for health promotion was established by the creation of the PNPS, which emphasises the guidelines and principles of the Ottawa Charter (WHO, 1986), as well as the assumptions of the SUS. The PNPS aims to promote quality of life by reducing vulnerability and minimizing health risks. Among its specific objectives is to prevent the determinants and conditioning factors of diseases and health problems (Brasil, 2006, 2014).

Because the National Strategic Action Plan to Battle Chronic NCDs in Brazil prioritises health promotion for the 20112022 period, the PNPS is highlighted. The plan and the PNPS intersect on actions to promote healthy eating and physical activity, as well as on the prevention of smoking and alcoholism (Brasil, 2006, 2011a). The plan to support the proposed actions and strategies presents the epidemiological profile of Brazil regarding the four main groups of chronic NCDs (circulatory system diseases, neoplasms, respiratory diseases and diabetes mellitus), designating smoking, alcoholism, physical inactivity, obesity and unhealthy eating as modifiable risk factors.

The Strategic Action Plan to Battle Chronic NCDs is based on three areas of activity - surveillance, data collection, evaluation and monitoring; health promotion; and comprehensive care-with the objective of promoting the development and implementation of effective, integrated, sustainable, evidence-based public policies aimed at the prevention and control of chronic NCDs and their risk factors. Another point presented in the plan is to seek to strengthen health care facilities that focus on the care of patients with chronic diseases (Brasil, 2012).

The Academy of Health Programme has become a venture to stimulate and expand health promotion actions, especially those aimed at reducing physical inactivity and obesity in Brazil. That occurs through the transfer of resources for the construction of infrastructure; that is, the centres (physical units) and the financing of actions developed by costing.

As explained in the Strategic Action Plan to Battle Chronic NCDs, health promotion is an important area for coordination and for building partnerships aimed at addressing the determinants of the health-illness process (Chart 1). That was imbued with " $[. .$.$] enabling interventions that have a positive impact by reducing the incidence of these diseases and their risk$ factors [...]" (Brasil, 2012, p. 15). 
Chart 1 - Priority actions for health promotion in the National Strategic Action Plan to Battle Chronic NCDs mentioned in the Academy of Health Programme in Brazil.

\begin{tabular}{|c|c|}
\hline \multicolumn{2}{|l|}{ Physical activity } \\
\hline Strategy & Description \\
\hline Academy of Health Programme & $\begin{array}{l}\text { Construction of healthy spaces that promote health and } \\
\text { stimulate physical activity/physical practices, leisure and } \\
\text { healthy lifestyles in coordination with primary health care }\end{array}$ \\
\hline Health at School Programme & $\begin{array}{l}\text { Universal access to Health at School Programme material } \\
\text { and financial incentives for all Brazilian municipalities }\end{array}$ \\
\hline Growth Acceleration Programme & $\begin{array}{l}\text { Strengthening of the public square construction component } \\
\text { of the Growth Acceleration Programme 2, on the citizen- } \\
\text { community axis, to integrate cultural activities, sports, } \\
\text { leisure, exercise, qualification for the labour market, social } \\
\text { assistance, violence prevention policies and digital inclusion, } \\
\text { providing coverage for all age groups }\end{array}$ \\
\hline Reformulation of healthy urban spaces & $\begin{array}{l}\text { Creation of the National Healthy Sidewalks Programme and } \\
\text { construction/refurbishing of bicycle paths, parks, public } \\
\text { squares and hiking trails }\end{array}$ \\
\hline Communication campaigns & $\begin{array}{l}\text { Creation of campaigns that encourage the practice of } \\
\text { physical activity and healthy habits, coordinated with major } \\
\text { events such as the World Cup (2014) and the Olympics } \\
\text { (2016) }\end{array}$ \\
\hline \multicolumn{2}{|l|}{ Active ageing } \\
\hline Comprehensive Health Care for the Elderly & $\begin{array}{l}\text { Implementation of a model of integrative care for active } \\
\text { ageing, favouring interventions aimed at health promotion, } \\
\text { disease prevention and comprehensive care }\end{array}$ \\
\hline Public Health Care Assistance & $\begin{array}{l}\text { Promotion of active ageing and public health care } \\
\text { interventions }\end{array}$ \\
\hline Academy of Health Programme & $\begin{array}{l}\text { Encouraging older people to practice regular physical } \\
\text { activity }\end{array}$ \\
\hline Primary health care team qualification & Training of primary health care teams of professionals \\
\hline Self-care and rational use of medications & $\begin{array}{l}\text { Promoting the expansion of autonomy and independence for } \\
\text { self-care and rational medication use }\end{array}$ \\
\hline Training of professional caregivers & $\begin{array}{l}\text { Creating programmes to train caregivers for the elderly and } \\
\text { people with chronic conditions in the community }\end{array}$ \\
\hline
\end{tabular}

Source: Brasil (2011).

As previously stated, the PNPS is based on the principles and guidelines of the SUS and approaches health promotion from a broad, positive perspective. In addition to its focus on controlling risk factors, especially those associated with chronic NCDs, the PNPS has the following objectives (Brasil, 2016): to expand the autonomy and co-responsibility of individuals and collectivities; to focus on health promotion actions at the primary health care level; to promote a broader concept of health; to 
encourage alternative, socially inclusive actions; to value and optimise public spaces as spaces for social interaction and health production; to preserve the environment and promote safe, healthy environments; to develop and implement integrated public policies; to expand the processes of integration through solidarity, cooperation and democratic participation; to encourage the adoption of nonviolent lifestyles and a culture of peace; and to value and expand cooperation and coordination among the various governmental and non-governmental spheres for the management of public policies to reduce inequality.

In Brazil, the field of health promotion is considered a work in progress, as it originates from a very recent, dynamic concept of health. Because of the oversights identified in its original (2006) version, the PNPS was recently revised, culminating in the issuance of Ordinance no. 2,446, in 2014. It is noteworthy that the first version of PNPS (Brasil, 2006) had a strong focus on risk factors and non-communicable diseases (chronic NCDs), and that the revised version added the notions of social determination of health and social production of health. The theoretical-conceptual differences between the two versions and the unique characteristics arising from the revision of the PNPS are presented in Chart 2.

Chart 2 - Theoretical-conceptual differences between the previous and current versions of the National Health Promotion Policy

\begin{tabular}{|c|c|c|}
\hline Component & Ordinance no. $687 \mathrm{MS} / G M(2006)$ & Ordinance no. 2,446 (2014) \\
\hline Concept & $\begin{array}{l}\text { A strategy of cross-sectional coordination that } \\
\text { increases the visibility of factors that put the health } \\
\text { of the population at risk, as well as highlighting the } \\
\text { differences between needs, territories and cultures } \\
\text { in Brazil }\end{array}$ & $\begin{array}{l}\text { A set of strategies and measures to produce } \\
\text { health, individually and collectively, } \\
\text { characterised by intrasectoral/intersectoral } \\
\text { coordination and cooperation }\end{array}$ \\
\hline Position & $\begin{array}{l}\text { Negative, focusing on risk factors, diseases and } \\
\text { illnesses }\end{array}$ & $\begin{array}{l}\text { Positive, focusing on health and its social } \\
\text { determinants }\end{array}$ \\
\hline Right to health & $\begin{array}{l}\text { Ensures equal, universal access to health care } \\
\text { services, as well as formulating social and } \\
\text { economic policies that reduce the risk of falling ill }\end{array}$ & $\begin{array}{l}\text { Requires the active participation of all } \\
\text { individuals in the analysis and formulation of } \\
\text { actions aimed at their promotion }\end{array}$ \\
\hline Overall objective & $\begin{array}{l}\text { To promote quality of life, reduce vulnerability and } \\
\text { control risks related to health determinants and } \\
\text { constraints-lifestyles, working conditions, } \\
\text { housing, environment, education, leisure, culture } \\
\text { and access to essential goods/services: }\end{array}$ & $\begin{array}{l}\text { To promote equity, improve living conditions } \\
\text { and modify lifestyles, expanding the individual } \\
\text { and collective health potential, reducing } \\
\text { vulnerability and controlling the health risks } \\
\text { arising from social, economic, cultural and } \\
\text { environmental determinants: }\end{array}$ \\
\hline \multirow{4}{*}{$\begin{array}{l}\text { Priority } \\
\text { themes/specific } \\
\text { actions }\end{array}$} & Healthy eating & Exercise and continuing education \\
\hline & Physical practice/physical activity & Proper, healthy eating \\
\hline & Smoking prevention and control & Physical practice and physical activity \\
\hline & $\begin{array}{l}\text { Reduction of morbidity and mortality due to } \\
\text { alcohol and drug abuse }\end{array}$ & $\begin{array}{l}\text { A focus on the use of tobacco and its } \\
\text { derivatives }\end{array}$ \\
\hline
\end{tabular}




\begin{tabular}{|l|l|l|}
\hline \multirow{2}{*}{} & $\begin{array}{l}\text { Reduction of morbidity and mortality due to traffic } \\
\text { accidents }\end{array}$ & A focus on alcohol abuse and other drug abuse \\
\cline { 2 - 3 } & $\begin{array}{l}\text { Prevention of violence and promotion of a culture } \\
\text { of peace }\end{array}$ & Promotion of safe mobility \\
\cline { 2 - 3 } & Promotion of sustainable development & $\begin{array}{l}\text { Promotion of a culture of peace and human } \\
\text { rights }\end{array}$ \\
\cline { 2 - 4 } & & Promotion of sustainable development \\
\hline Orientation & Preventive and risk reduction & Promotion of health and social determination \\
\hline
\end{tabular}

Source: Brasil (2006, 2014).

The first wave of health promotion, which was in alignment with the first version of the PNPS, was based on the concept of prevention, being positioned as an appendix to the biomedical model. Therefore, health promotion is one of the levels of prevention, designated primary prevention (Buss, 2003). The revised version of the PNPS incorporates concepts and practices linked to the second wave of health promotion.

The normative-legal documents related to the PNPS place great emphasis on the conceptual framework of health promotion, seeking to intervene in the lifestyles of individuals, especially in terms of the impact that risk factors associated with obesity and physical inactivity have on morbidity and mortality. Within that context, the Brazilian National Ministry of Health created the Academy of Health Programme in 2011, with the objectives of making it a focal point and implementing actions linked to the PNPS.

The Academy of Health Programme was established under the auspices of the SUS, so that the PNPS could be more fully implemented (Brasil, 2011b). The focus of the ordinance that created the programme was on providing opportunities for coordinating and enhancing joint actions of primary health care, health surveillance and health promotion. Ordinance no. 2,681, which redefined the programme in 2013, underscored the need to integrate primary health care and health surveillance actions focused on health promotion, disease prevention and the treatment of NCDs. Article 2 of the ordinance outlines the central objective of the programme (Brasil, 2011b, p. 1): "[ . . ] to promote health, provide care and encourage healthy lifestyles by establishing centres with the appropriate infrastructure and staffed by qualified professionals."

In its initial incarnation, the Academy of Health Programme established the conditions for the systematisation of individual and collective actions, based on the first version of the PNPS. With the objective of addressing the progression of chronic NCDs and meeting the goals established in the National Strategic Action Plan to Battle Chronic NCDs, the Academy of Health Programme functions from the perspective of prevention, seeking to control health risk factors while considering the behavioural aspects and lifestyle of individuals. Nevertheless, the programme brings references linked to the field of collective health from a broader perspective, as well as concepts arising from the critical strand of physical education itself, especially by incorporating the concept of physical practices and the notion of body culture, creating the conditions to build a path to autonomy and emancipation for individuals.

The revised (2014) version of the PNPS incorporates community participation into its principles, values and guidelines. As a principle, social participation is defined as intervention based on the views of different actors, individually and collectively. Those views are necessary to identify the demands and needs of the various regions and work together in the decision-making process, as well as in the planning, launching, implementation and evaluation 


\section{Final Considerations}

Given that health promotion is a nascent theoretical-conceptual and empirical construct, in Brazil and worldwide, discussions related to the field can be fruitful. The transition to a health promotion model represents a process of paradigmatic change in the health field. Nevertheless, it must be considered that such a transition leads to the creation of new public policies and, consequently, hybrid government programmes. This hybridism is directly attributable to the coexistence of the preceding paradigm (the biomedical model) and the emerging paradigm (the social production of health model).

Some regard health promotion simply as window dressing for the biomedical model. However, unlike the biomedical model, which has a negative bias, the health promotion model takes a positive tack as a movement aimed at improving quality of life. Others suggest that it provides a new label for the hegemonic, uncritical, neoliberal model, casting the health promotion model in the role of successor to the traditional model and using succession strategies to bring about that change (Bourdieu, 1983). Even some authors working in the field of collective health criticise the health promotion model, pointing out failing s related to its creation as a non-partisan initiative that abandons the political-ideological struggle (Lefevre \& Lefevre, 2004). For Lefevre e Lefevre (2004), it is crucial that Public Health subverts this use of health promotion and uses it as a proxy for the emerging social production of health model. As those authors put it, "As a transformative proposal, public or collective health needs to react to this attempt to undermine its pillars, maintaining, as its 'greater mission', the theoretical and practical fight, here and now, against disease [. . .]" (Lefevre \& Lefevre, 2004, p. 166).

It is evident that the revised PNPS explores new possibilities and a new vision of health, aligned with collective health. Unlike its initial version, which proposed specific actions to support what became the National Strategic Action Plan to Battle Chronic NCDs, the revised PNPS represents an attempt to break with a perspective focused on illness and on regulation of the bodies and lives of individuals, supporting the creation of projects and programmes that focus on reducing the rates of hospitalisation and mortality associated with the four main groups of chronic NCDs. One of the most notable of such programmes is the Academy of Health Programme.

At the time of its development, the Academy of Health Programme had a strong influence from the biomedical model, because its theoretical and legal framework included many elements of the first version of the PNPS (Brasil, 2006) and of the National Strategic Action Plan to Battle Chronic NCDs (Brasil, 2011a). At its core, the programme primarily focuses on reducing the rates of physical inactivity and obesity, as well as improving fitness and coping with chronic NCDs related to unhealthy lifestyles. However, it also includes elements that are in line with the new concept of health promotion, linked to emancipation and social empowerment, in which the population, individually and collectively, can decide about their bodies, health and lives, as a an exercise in citizenship and a guarantee of fundamental human rights.

The importance of strengthening actions that reduce mortality due to chronic NCDs in the population under 70 years of age cannot be overstated. However, it is crucial to understand, from a critical perspective, that health is an element that depends on social, cultural, economic and environmental aspects, requiring that new practices and concepts transcend the overvaluation of epidemiology and of the biomedical (preventive, curative, hygiene-oriented and biology-oriented) model.

Lefevre e Lefevre (2007) asserted that, for a new paradigm to be established, it is necessary to break the bonds with the preceding paradigm, and that, to do so, it is necessary to undergo a process of denial of denial, especially in relation to health promotion. Health promotion will effectively be an emancipatory health practice only when it refutes the established sociopolitical system, the legitimised paradigm of which has a preventive-curative slant and focuses on blaming individuals for the ills they experience.

The Academy of Health Programme, being a newly created government programme, has resulted in hybridisations between health paradigms that coexist in the SUS. The programme incorporates practices for controlling and regulating attitudes and behaviours aimed at reducing the morbidity and mortality associated with chronic NCDs, upholding, through the 
establishment of norms, principles and values capable of fostering a participatory, more democratic society with social advocacy. Therefore, the Academy of Health Programme can and should create a space where, beyond the chronic NCDs, the model of dominator and dominated can be subverted and the transformation idealised by collective health through the health promotion movement can be made concrete.

\section{References}

Agamben, G. (2017). O uso dos corpos. Boitempo.

Bardin, L. (2011). Análise de conteúdo. Edições 70.

Bertolli Filho, C. (2011). História da saúde pública no Brasil. (5a ed.), Ática.

Bourdieu, P. (1983). O Campo Científico. In: Ortiz, R. Pierre Bourdieu [tradução de Paula Montero \& Alicia Auzmendi. Ática.

Brasil. (2006). Portaria 687, de 30 de Março de 2006 - Aprova a Política Nacional de Promoção Da Saúde (PNPS). Brasília: Ministério Da Saúde.

Brasil. (2011a). Ministério da Saúde. Secretaria de Vigilância em Saúde. Departamento de Análise de Situação de Saúde. Plano de ações estratégicas para o enfrentamento das Doenças Crônicas Não Transmissíveis (DCNT) no Brasil 2011-2022 / Ministério da Saúde. Secretaria de Vigilância Em Saúde. Departamento de Análise de Situação de Saúde. - Brasília: Ministério da Saúde.

Brasil. (2011b). Portaria No 719/Gm/Ms, de 7 de Abril de 2011 - Institui o Programa Academia da Saúde no âmbito do Sistema Único de Saúde. Brasília : Ministério da Saúde.

Brasil. (2014). Portaria 2.446, de 11 de novembro de 2014 - Redefine a Política Nacional de Promoção Da Saúde (PNPS). Brasília: Ministério da Saúde.

Brasil. (2017). Portaria de Consolidação No 2, de 28 de setembro de 2017 - Consolidação das normas sobre as políticas nacionais de saúde do Sistema Único de Saúde. Brasília: Ministério da Saúde.

Buss, P. M. (2003). Uma introdução ao conceito de promoção da saúde. In: Czeresnia, D, Freitas, Cm (org.). Promoção da Saúde: Conceitos, Reflexões, Tendências. Rio De Janeiro: Ed. Fiocruz.

Butler, J. (2015). Quadros de Guerra: Quando a vida é passível de luto? Civilização Brasileira.

Carvalho, S. R. (2004). As contradições da promoção da saúde em relação à produção de sujeitos e a mudança social. Ciência \& Saúde Coletiva, Rio de Janeiro, 9 (3), 669-678. http://dx.doi.org/10.1590/S1413-81232004000300018

Carvalho, S. R. (2013). Saúde Coletiva e Promoção da Saúde: sujeito de mudança. (3a ed.), Hucitec.

Czeresnia, D. (2003). O conceito de saúde e a diferença entre prevenção e promoção. In: Czeresnia, D, Freitas, Cm (org.). Promoção Da Saúde: Conceitos, Reflexões, Tendências. ed. Fiocruz.

Fontes, O. L. (1995). Além dos sintomas: superando o paradigma saúde e doença. Prefácio de Gilberto Luiz Pozetti. Piracicaba: Editora Unimep.

Foucault, M. (1977). O Nascimento da Clínica. Tradução Roberto Machado. Rio de Janeiro: Forense-Universitária.

Giddens, A. (2009). A Constituição da Sociedade. (3a ed.) Ed. Martins Fontes.

Giddens, A. (1991). As Consequências da Modernidade. Ed. Unesp.

Heidmann, I. T. S., Almeida, M. C. P, Boehs, A. E, Wosny, A. M, Monticelli, M. (2006). Promoção da saúde: trajetória histórica de suas concepções. Contexto Enfermagem, Florianópolis, Abr.-jun., 15 (2), 352-358. http://dx.doi.org/10.1590/S0104-07072006000200021.

Ianni, A. M. Z (2008). Saúde pública e sociedade de risco. Revista de Direito Sanitário, São Paulo, 8(3), 38-48. https://doi.org/10.11606/issn.2316-9044.v8i3p3848

Kingdon, J. W. (1995). Agenda Setting. In: Theodoulou, Sz.; Cahn, Ma. Public Policy: The Essencial Readings. New Jersey: Prentice Hall.

Kuhn, T. S. (1962). A Estrutura das Revoluções Científicas. (5a ed.) Editora Perspectiva.

Lefevre, F, \& Lefevre, A. M. C. (2004). Promoção de Saúde: a negação da negação. Vieira \& Lent.

Lefevre, F., Lefevre, A. M. C. (2007). A promoção de saúde como oportunidade para a emancipação. Revista Eletrônica de Comunicação e Informação \& Inovação em Saúde. Rio De Janeiro, 1(2), 234-240, 2007. https://doi.org/10.3395/reciis.v1i2.907

Lopes, O. C. (1970). A Medicina no Tempo: Notas de história da medicina. Editora Da Universidade De São Paulo.

Mendes, E.V. (1996). Uma Agenda para a Saúde. Hucitec.

Mendes, V.M., Carvalho, Yara M. (2016). Práticas Corporais e Clínica Ampliada. Hucitec: Capes.

Minowa, E. (2016). Produção científica dos grupos de pesquisa em promoção da saúde no Brasil: perfil e discussão de uma amostra nacional. Dissertação (Mestrado Em Ciências). São Paulo: Programa de Pós-Graduação em Saúde Pública, Universidade de São Paulo. 
Research, Society and Development, v. 10, n. 1, e22910111642, 2021

(CC BY 4.0) | ISSN 2525-3409 | DOI: http://dx.doi.org/10.33448/rsd-v10i1.11642

Paim, J.S. (2009). O que é o SUS. Rio de Janeiro: Editora Fiocruz.

Rocha, P. R., David, H.M.S. (2015). Determinação ou determinantes? Uma discussão com base na teoria da produção social da saúde. Revista da Escola de Enfermagem da USP, 49(1), 129-135. https://doi.org/10.1590/S0080-623420150000100017

Rosen, G. (1979). Da polícia médica à medicina social: ensaios sobre a história da assistência médica. Tradução: Ângela Loureiro de Souza. Rio de Janeiro: Graal.

Sabatier, P. A. (1995). Political Science And Public Policy. In: Theodoulou, Stella, Z.; Cahn, Matthew A. Public Policy: The Essencial Readings. New Jersey: Prentice Hall.

Sabatier, P. A., \& Weible, C. M. (2007). The Advocacy Coalition Framework: Innovations and Clarifications. In: Sabatier, P.A. Theories of the Policy Process. Colorado: Westview Press.

Santos, B. S. (1987). Um discurso sobre as ciências. (5a ed.), Cortez Editora.

Santos, J. F. F., \& Westphal, M. F. (1999). Práticas emergentes de um novo paradigma de saúde: o papel da universidade. Estudos Avançados, São Paulo, 13 (35), 71-88. https://doi.org/10.1590/S0103-40141999000100007

Scliar, M. (2005). Do mágico ao social: trajetória da saúde pública. (2a ed.), Senac.

Withelaw, S., Baxendale, A., Bryce, C., Machardy L., Young, I., Witney, E. (2001). 'Settings' based Health Promotion: A Review. Health Promotion Int, Oxford Academic: 16 (4): 339-353. 10.1093/Heapro/16.4.339

World Health Organization (1986). The Ottawa Charter for Health Promotion. Ottawa. 